\title{
THE EFFECT OF PRENATAL EXPOSURE ON DISPOSITION OF HEXACHLORONAPHTHALENE IN FEMALE WISTAR RATS AND FETAL COMPARTMENT
}

\section{JOANNA STRAGIEROWICZ ${ }^{1}$, KRYSTYNA SITAREK ${ }^{2}$, BARTŁOMIEJ GROBELSKI ${ }^{3}$, and ANNA KILANOWICZ ${ }^{1}$}

\author{
${ }^{1}$ Medical University of Lodz, Łódź, Poland \\ Faculty of Pharmacy, Department of Toxicology \\ ${ }^{2}$ Nofer Institute of Occupational Medicine, Łódź, Poland \\ Department of Toxicology and Carcinogenesis \\ ${ }^{3}$ Medical University of Lodz, Łódź, Poland \\ Faculty of Pharmacy
}

\begin{abstract}
Objectives: Due to structural and toxicological similarities to 2,3,7,8-tetrachlorodibenzo-p-dioxin (TCDD), polychlorinated naphthalenes (PCNs) were included in the Stockholm Convention on Persistent Organic Pollutants (POPs) in 2015. Hexachloronaphthalene $(\mathrm{HxCN})$ is considered to be one of the most toxic congeners of PCNs. The objective of this study was to determine the maternal and fetal tissue concentrations of hexachloronaphthalene after a single administration. Material and Methods: Pregnant female Outbred Wistar rats were used for the study. The $\left[{ }^{14} \mathrm{C}\right]-\mathrm{HxCN}$ was administered in a single oral dose of $0.3 \mathrm{mg} / \mathrm{rat}$ (150 kBq/rat) on gestational day 17 (GD17), GD18 or GD19. All dams were sacrificed on GD20. The blood and selected tissue samples taken from mothers and fetuses $24 \mathrm{~h}, 48 \mathrm{~h}$ or $72 \mathrm{~h}$ after exposure were evaluated for the distribution of $\mathrm{HxCN}$. Results: Maximum concentrations of $\mathrm{HxCN}$ in pregnant rats were found in the liver and adipose tissue. Relatively high levels of $\mathrm{HxCN}$ were also reported in the spleen, ovaries, adrenal glands and uterus, as well as in the sciatic nerve, brain and kidneys. Hexachloronaphthalene penetrates through the blood-brain barrier (BBB), as evidenced by twice the concentration in the brain compared to the blood concentration, and through the placental barrier, as indicated by the level of maternal-fetal compartment (placenta, amniotic fluid, litter). Among the examined fetal tissues, the highest levels of $\mathrm{HxCN}$ were found in the kidneys and in the brain. The concentrations in these organs were higher than that found in the maternal blood. Conclusions: This paper is the first to detail the concentrations of $\mathrm{HxCN}$ in the maternal tissues and the transplacental transfer of the tested compound to the fetuses. The exposure of pregnant rats to HxCN results in its accumulation in the maternal liver, fat tissue, reproductive and nervous system, and particularly in the fetal brain. This demonstrates both the effective absorption and significant systemic accumulation which could lead to negative health implications. Int J Occup Med Environ Health 2018;31(5):685-695
\end{abstract}

Key words:

Hexachloronaphthalene, Disposition, Fetal compartment, Pregnant rat, Polychlorinated naphthalenes, Transplacental transfer

Funding: this study was in part supported by National Science Centre (grant No. NN 404271240 entitled "Prenatal toxicity of selected environmental poisons from the Persistent Organic Pollutants (POPs) group - Tetrachloronaphthalene and hexachloronaphthalene," grant manager: Prof. Anna Kilanowicz) and by Medical University of Lodz (grant No. 503/3-045-01/503-31-001 entitled "Issues of toxicology of organic compounds of environmental importance and selected metals," grant manager: Prof. Anna Kilanowicz).

Received: September 7, 2017. Accepted: January 3, 2018.

Corresponding author: Joanna Stragierowicz, Medical University of Lodz, Faculty of Pharmacy, Department of Toxicology, Muszyńskiego 1, 90-151 Łódź, Poland (e-mail: joanna.stragierowicz@umed.lodz.pl). 


\section{INTRODUCTION}

Polychlorinated naphthalenes (PCNs) include 75 congeners that had been widely used in various industries until the end of 1980s in the form of various mixtures, mainly as capacitor fluids, engine oil additives, cable insulation additives and for wood and paper impregnation [1]. In 2015, these compounds were included in Annex A and $\mathrm{C}$ of the Stockholm Convention, which prohibits their production and imposes the need to control their emissions during various industrial processes [2], due to their physicochemical properties being similar to those of persistent organic pollutants (POPs).

Currently, the main sources of PCNs in the environment are considered to be emissions from older products, i.e., technical preparations of PCNs, polychlorinated biphenyls (PCBs) and other similar compounds where PCNs occurred as impurities, as well as high-temperature industrial processes, during which PCNs are still formed as unintentional by-products [3-5]. These processes increase environmental contamination [6,7], and greater exposure of the general population to PCNs. This exposure occurs primarily through food [8-11]; for instance, it has been found that polychlorinated naphthalenes represent about $5 \%$ of the total toxic equivalence (TEQ) value (PCNs, polychlorinated dibenzodioxins - PCDDs; and PCBs) in butter and cheese [11]. Theoretically, the dietary exposure should not be as significant as in the case of dioxins. Falandysz et al. [12] confirmed the relative potencies (REPs) of selected hexa- and heptachloronaphthalene congeners $(0.002-0.003)$.

Some hexachloronaphthalene $(\mathrm{HxCN})$ isomers may be classified as having an order of magnitude grater dioxinlike potency as compared to octachloro- and octabromo dibenzo-p-dioxin and dibenzofuran [12]. Despite the low value of TEQ in food, their lipophilic properties allow PCNs to accumulate to high levels in the body, especially in the liver [13] and adipose tissue [14,15]. This has been confirmed by numerous studies carried out in a number of countries: in Sweden [13,16], Germany [17], Italy [15], and in the United States [14]. Their presence was also confirmed in the blood [1], in the milk of lactating women [16], as well as in umbilical cord blood [18,19]. Therefore, it indicates not only a significant accumulation of PCNs in the whole body, but also suggests that these compounds are likely to easily penetrate the placenta and may be dangerous to developing fetuses.

The prenatal period is particularly sensitive as far as exposure to toxic substances is concerned. During this time it is not only the maternal body that is responsible for the metabolism of xenobiotics but also the placenta, the activity of which is manifested by the induction of a variety of enzymes including CYP1A1, i.e., isoforms considered to be a marker for prenatal $\mathrm{HxCN}$ exposure [20]. Our previous studies show that $\mathrm{HxCN}(0.1-1 \mathrm{mg} / \mathrm{kg}$ body weight (b.w.)) administration to females during organogenesis is associated with very strong embryotoxic effects [20] whereas a mixture of diverse congeners of PCNs with a similar composition to the previously used Halowax resulted in not only embryotoxic but also fetotoxic and teratogenic effects [21]. This prenatal toxicity may be due to the toxic mechanisms or to the transport of the compound through the placenta.

Among the all PCNs congeners, hexachloronaphthalene is one of the most bioaccumulative [22-24] and toxic [2527]. So far, no research has been carried out that would confirm the penetration of PCNs through the placental barrier. Therefore, the aim of this study was to evaluate the maternal and fetal concentration of $\mathrm{HxCN}$, and its transplacental transport to the fetus, after the administration of a single dose of $\left[{ }^{14} \mathrm{C}\right]$ hexachloronaphthalene to pregnant rats on selected days of pregnancy.

\section{MATERIAL AND METHODS}

\section{Chemicals}

${ }^{14} \mathrm{C}$-labeled hexachloronaphthalene $\left(\left[{ }^{14} \mathrm{C}\right]-\mathrm{HxCN}\right)$ with a specific activity of $500 \mathrm{MBq} / \mathrm{g}$ was obtained from the Institute of Applied Radiation Chemistry, the Faculty of 
Chemistry, the Lodz University of Technology, Poland, as a mixture of isomers $\left[{ }^{14} \mathrm{C}\right]-\mathrm{HxCN}$ (over 94\%) and it contained mainly $\left[{ }^{14} \mathrm{C}\right]-1,2,3,5,6,7-\mathrm{HxCN}(81 \%)$. Other chemicals used were of the highest commercially available grade.

\section{Animals}

All experimental procedures were carried out according to the Directive of the European Parliament and the Council (2010/63/UE) concerning the protection of animals used for scientific purposes [28]. The investigations were performed with the permission of the Local Ethical Committee for Experimentation on Animals of Łódź, Poland (No. 42/ŁB 478/2009).

The experiments were performed on adult pregnant female Wistar rats (aged 8 weeks) from the breeding colony of the Nofer Institute of Occupational Medicine, Lódź, Poland (IMP: WIST rats). The animals were supplied at least 1 week before the experiment. They were fed a standard pelletized diet of Murigram (Agropol, Motycz, Poland) and had free access to water. The exposed rats were housed 5 per cage (cage size: $35 \times 55 \times 25 \mathrm{~cm}$ ) at the room temperature of $21-23^{\circ} \mathrm{C}$, and humidity equaling $55 \pm 5 \%$. The animals were maintained in a constant light/dark cycle of 12/12 h. Female rats were paired overnight with male rats in the ratio 2:1. On the following day, the presence of sperm in the vaginal smears was checked by microscopy to confirm pregnancy. When sperm was detected, the day was designated as gestational day 0 (GD 0 ) of pregnancy.

\section{Animal treatment}

The $\left[{ }^{14} \mathrm{C}\right]-\mathrm{HxCN}$ was dissolved in sunflower oil and administered to the pregnant female rats (5 animals/ group were used per time point) directly intragastrically (per os) via a metal gastric tube in a single dose of about $0.3 \mathrm{mg}(150 \mathrm{kBq})$ per animal in the volume of $0.5 \mathrm{ml}$ per rat. The dams received a single oral dose on GD 17, GD 18 or GD 19. The applied dosage was the same as we used in our previous study [24].

\section{Preparation of the biological samples}

Females weighing $309 \pm 18 \mathrm{~g}$ were sacrificed on gestational day 20 (GD 20) - 72 h, $48 \mathrm{~h}$ or $24 \mathrm{~h}$ after the compound administration, respectively. The animals were decapitated and the maternal and fetal tissues were collected for radioactivity determination. The maternal liver, kidneys, lungs, brain, spleen, uterus and placenta were homogenized. The adrenals, sciatic nerve, a piece of abdominal fat, skin (ear) and muscular tissue from the quadriceps femoral muscle were digested directly.

The mean litter size was $10.1 \pm 1.75$ fetuses per litter, irrespective of the exposure group. Two fetuses were selected randomly from each litter and homogenized as a whole. From the remaining fetuses livers, brains, kidneys, skin fragments, and amniotic fluid were removed and digested directly. After the collection of the above-mentioned organs and tissues, carcasses were homogenized.

\section{Measurements of radioactivity}

Aqueous tissue homogenates $(20 \%)$ and blood were digested according to Mahin and Lofberg [29] before radioactivity measurements. All measurements were carried out using Racbeta 1209 (LKB, Sweden) liquid scintillation counter and EcoLume ${ }^{\mathrm{TM}}$ from MP Biomedicals, LLC (USA) as the scintillation mixture. Counting correction was achieved using the external standard method. In parallel, the $\left[{ }^{14} \mathrm{C}\right]-\mathrm{HxCN}$ standard was measured, which allowed to convert $\mathrm{kBq}$ to $\mu \mathrm{g} \mathrm{HxCN}$.

\section{Data analysis}

The data was analyzed in the following dose metric units: \% dose/tissue, \% dose/g tissue and $\mu \mathrm{g} \mathrm{HxCN} / \mathrm{g}$ tissue. However, radioactivity was measured only in the selected organs and tissues or in the sections of tissues. Hurst et al. [30] recorded that on GD 20 the muscle tissue in pregnant females represented approx. 33\% of the rat weight, the adipose tissue - about $10 \%$, skin - about $9 \%$, and blood - circa about $7.7 \%$. These values were used for calculating the $\%$ of the administrated dose per whole tissue. 


\section{Statistical methods}

Intergroup comparisons were performed by the one-way analysis of variance (ANOVA). When statistically significant effects were detected in the overall analysis of variance, means were compared with the post hoc Tukey's test. In all statistical analyzes, the value of $p<0.05$ was considered to indicate statistical significance. The calculation was performed using Statistica 10.1 software.

\section{RESULTS}

\section{Maternal $\mathrm{HxCN}$ tissue concentrations}

The concentration of HxCN 24 h, 48 h or $72 \mathrm{~h}$ after a single oral administration of $\left[{ }^{14} \mathrm{C}\right]-\mathrm{HxCN}$ in the maternal tissues is shown in Table 1 and Figure 1. The study showed that for all time points, the highest amount of hexachloronaphthalene in the body of pregnant rats was found in the maternal liver, followed by the adipose tissue. The values obtained for the liver ranged between $24.5-26.7 \%$ dose/ tissue $24 \mathrm{~h}$ and $72 \mathrm{~h}$ after exposure (Figure 1). The concentrations of $\mathrm{HxCN}$ in the adipose tissue, expressed as $\mu \mathrm{g} \mathrm{HxCN} / \mathrm{g}$ tissue, were more than 3-4 times lower than the ones recorded for the liver (Table 1) and allowed to calculate the $\mathrm{L} / \mathrm{A}$ ratio (concentration of $\mathrm{HxCN}$ in the liver to the concentration in the adipose tissue), which was as follows: 4.75 after $24 \mathrm{~h} ; 3.48$ after $48 \mathrm{~h}$ and 3.19 at $72 \mathrm{~h}$ after administration.

Relatively high levels of $\mathrm{HxCN}$ were also found in the spleen, adrenals, ovaries, uterus and sciatic nerve,

Table 1. Concentration of hexachloronaphthalene $(\mathrm{HxCN})$ in maternal tissues after a single oral dose of $0.3 \mathrm{mg}\left[{ }^{14} \mathrm{C}\right]-\mathrm{HxCN}$ per rat

\begin{tabular}{|c|c|c|c|c|c|c|}
\hline \multirow{3}{*}{$\begin{array}{l}\text { Tissue } \\
(\mathrm{N}=5)\end{array}$} & \multicolumn{6}{|c|}{$\begin{array}{l}\mathrm{HxCN} \text { concentration } \\
(\mathrm{M} \pm \mathrm{SD})\end{array}$} \\
\hline & \multicolumn{3}{|c|}{$\mu \mathrm{g} \mathrm{HxCN/g}$ tissue } & \multicolumn{3}{|c|}{$\%$ of maternal dose/g or ml tissue } \\
\hline & after $24 \mathrm{~h}$ & after $48 \mathrm{~h}$ & after $72 \mathrm{~h}$ & after $24 \mathrm{~h}$ & after $48 \mathrm{~h}$ & after $72 \mathrm{~h}$ \\
\hline Liver & $5.39 \pm 0.84$ & $5.28 \pm 0.72$ & $5.58 \pm 0.7$ & $1.79 \pm 0.23$ & $1.77 \pm 0.21$ & $1.86 \pm 0.2$ \\
\hline Kidney & $0.26 \pm 0.02$ & $0.24 \pm 0.02$ & $0.22 \pm 0.02$ & $0.08 \pm 0.005$ & $0.08 \pm 0.004$ & $0.07 \pm 0.005$ \\
\hline Adrenal & $0.42 \pm 0.01$ & $0.44 \pm 0.01$ & $0.41 \pm 0.01^{\mathrm{b}}$ & $0.14 \pm 0.005$ & $0.15 \pm 0.005$ & $0.13 \pm 0.004$ \\
\hline Lung & $0.28 \pm 0.02$ & $0.26 \pm 0.01$ & $0.20 \pm 0.01^{\mathrm{a}, \mathrm{b}}$ & $0.09 \pm 0.004$ & $0.09 \pm 0.003$ & $0.09 \pm 0.003$ \\
\hline Spleen & $1.04 \pm 0.05$ & $0.86 \pm 0.06^{\mathrm{a}}$ & $0.82 \pm 0.06^{\mathrm{a}}$ & $0.33 \pm 0.01$ & $0.29 \pm 0.01$ & $0.27 \pm 0.01$ \\
\hline Brain & $0.18 \pm 0.009$ & $0.24 \pm 0.01^{\mathrm{a}}$ & $0.30 \pm 0.02^{\mathrm{a}, \mathrm{b}}$ & $0.06 \pm 0.001$ & $0.08 \pm 0.001$ & $0.10 \pm 0.01$ \\
\hline Sciatic nerve & $0.26 \pm 0.03$ & $0.26 \pm 0.02$ & $0.38 \pm 0.02^{\mathrm{a}, \mathrm{b}}$ & $0.09 \pm 0.006$ & $0.09 \pm 0.004$ & $0.13 \pm 0.007$ \\
\hline Ovary & $0.71 \pm 0.05$ & $0.71 \pm 0.05$ & $0.81 \pm 0.02^{\mathrm{a}, \mathrm{b}}$ & $0.23 \pm 0.01$ & $0.23 \pm 0.01$ & $0.27 \pm 0.01$ \\
\hline Uterus & $0.42 \pm 0.02$ & $0.42 \pm 0.01$ & $0.42 \pm 0.01$ & $0.14 \pm 0.007$ & $0.14 \pm 0.006$ & $0.14 \pm 0.006$ \\
\hline Placenta & $0.16 \pm 0.01$ & $0.18 \pm 0.01$ & $0.18 \pm 0.01$ & $0.05 \pm 0.001$ & $0.06 \pm 0.001$ & $0.06 \pm 0.001$ \\
\hline Amniotic fluid & $0.18 \pm 0.02$ & $0.20 \pm 0.02$ & $0.20 \pm 0.02$ & $0.06 \pm 0.001$ & $0.07 \pm 0.001$ & $0.07 \pm 0.001$ \\
\hline Fat & $1.24 \pm 0.05$ & $1.62 \pm 0.07$ & $1.72 \pm 0.07^{\mathrm{a}}$ & $0.41 \pm 0.01$ & $0.54 \pm 0.01$ & $0.57 \pm 0.01$ \\
\hline Muscle & $0.06 \pm 0.005$ & $0.08 \pm 0.001$ & $0.08 \pm 0.001$ & $0.02 \pm 0.001$ & $0.03 \pm 0.001$ & $0.03 \pm 0.001$ \\
\hline Blood & $0.15 \pm 0.005$ & $0.16 \pm 0.005$ & $0.16 \pm 0.005$ & $0.05 \pm 0.001$ & $0.05 \pm 0.001$ & $0.05 \pm 0.001$ \\
\hline Skin & $0.16 \pm 0.01$ & $0.22 \pm 0.02^{\mathrm{a}}$ & $0.24 \pm 0.02^{\mathrm{a}}$ & $0.06 \pm 0.001$ & $0.07 \pm 0.005$ & $0.08 \pm 0.001$ \\
\hline
\end{tabular}

$\mathrm{N}$ - number of samples; $\mathrm{M}$ - mean; SD - standard deviation.

a Significantly different from the "after 24 h" group within the same tissue (Tukey's test, $\mathrm{p}<0.05$ ).

b Significantly different from the "after $48 \mathrm{~h}$ " group within the same tissue (Tukey's test, $\mathrm{p}<0.05$ ). 

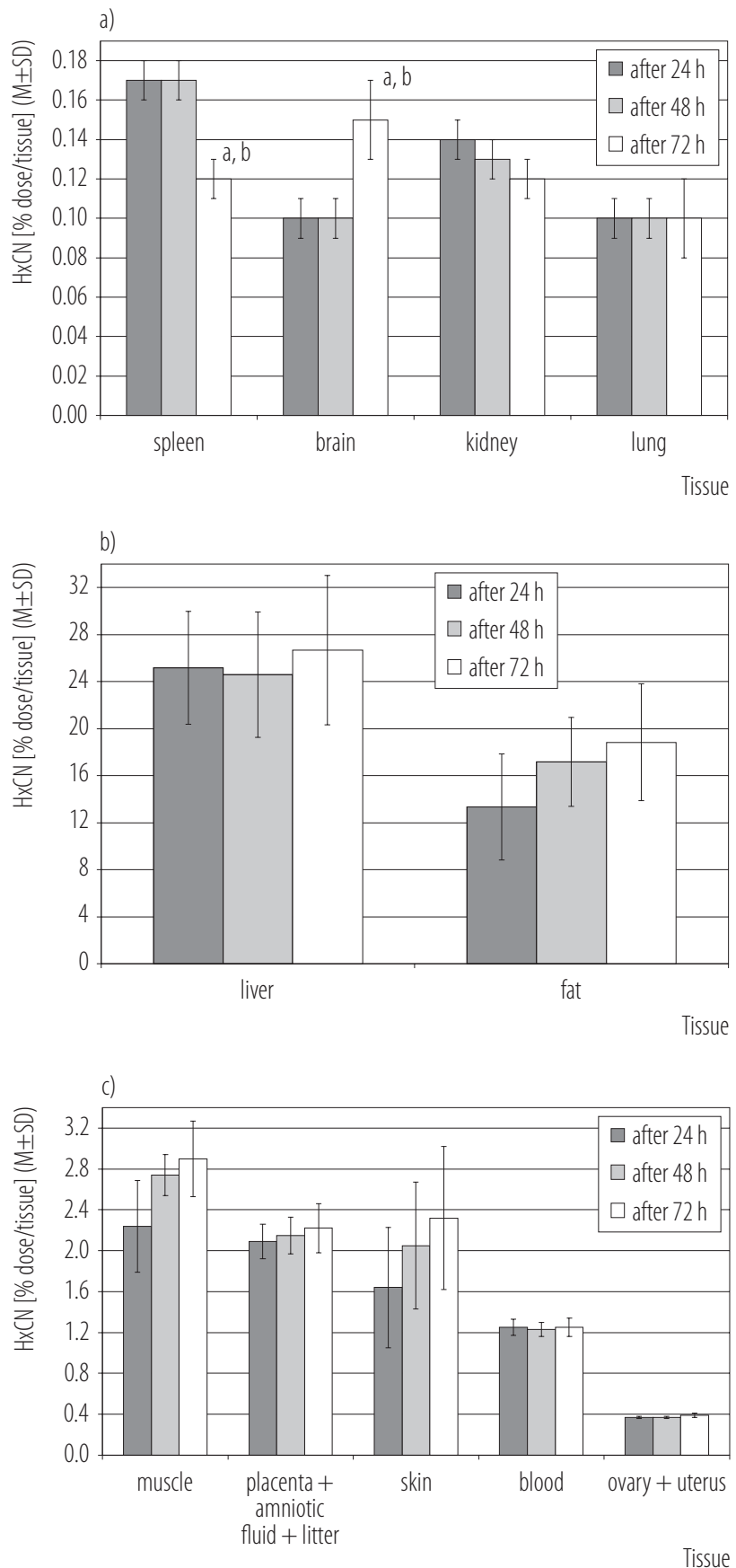

Abbreviations as in Table 1.

Fig. 1. Amount of hexachloronaphthalene $(\mathrm{HxCN})$ in maternal tissues after a single oral dose of $0.3 \mathrm{mg}\left[{ }^{14} \mathrm{C}\right]-\mathrm{HxCN}$ per rat

which contained 0.82-1.04 $\mu \mathrm{g} \mathrm{HxCN} / \mathrm{g}, 0.71-0.81 \mu \mathrm{g}$ $\mathrm{HxCN} / \mathrm{g}, 0.42 \mu \mathrm{g} \mathrm{HxCN} / \mathrm{g}$ and $0.26-0.38 \mu \mathrm{g} \mathrm{HxCN} / \mathrm{g}$, respectively. The $\mathrm{HxCN}$ concentration in these organs was approx. 2-3 times higher than in the blood, suggesting that the compound had a strong affinity to these organs. The concentrations in the blood ranged 0.15$0.16 \mu \mathrm{g} \mathrm{HxCN} / \mathrm{ml}$ (Table 1).

It is interesting to note that there was a time-dependent increase of $\mathrm{HxCN}$ (\% dose/tissue) observed in the skin, muscle tissue, fat tissue and brain (Figure 1).

Hexachloronaphthalene penetrates through the bloodbrain barrier, as evidenced by the fact that the maximum concentration in the brain, observed after $72 \mathrm{~h}$, was more than 1.5 times higher than in the blood. About 3 times higher $\mathrm{HxCN}$ concentration in sciatic nerve than in the blood could indicate affinity of hexachloronaphthalene to the neural tissue (Table 1). Three days after the administration, on GD 20, the total $\mathrm{HxCN}$ amount accumulated in the examined organs and tissues in the maternal body equaled more than $50 \%$ of the single administered dose of the tested compound, which demonstrated both effective absorption from the gastrointestinal tract and systemic accumulation, noted especially in the liver and adipose tissue.

\section{Fetal HxCN tissue concentrations}

It was found that $\mathrm{HxCN}$ may also easily defeat the placental barrier, as indicated by the levels of the compound deposited in the fetal compartment (placenta, amniotic fluid, and all the fetuses per litter) and in the whole fetus, where approx. $2 \%$ and $0.17 \%$ of the given dose was recorded $72 \mathrm{~h}$ after single administration, respectively (Figure 1, Table 2). The dose of $0.3 \mathrm{mg} \mathrm{HxCN}$ per animal resulted in a whole fetus concentration of approx. $0.05 \%$ of the administered dose/g tissue, regardless of the time after exposure. The livers, brains and kidneys from individual fetuses were analyzed to find the potential target tissue. Table 2 shows the $\mathrm{HxCN}$ levels in the selected organs of the fetuses. In the majority of cases, no significant differences in $\mathrm{HxCN}$ concentrations were found between the time points, and the values were characterized by 


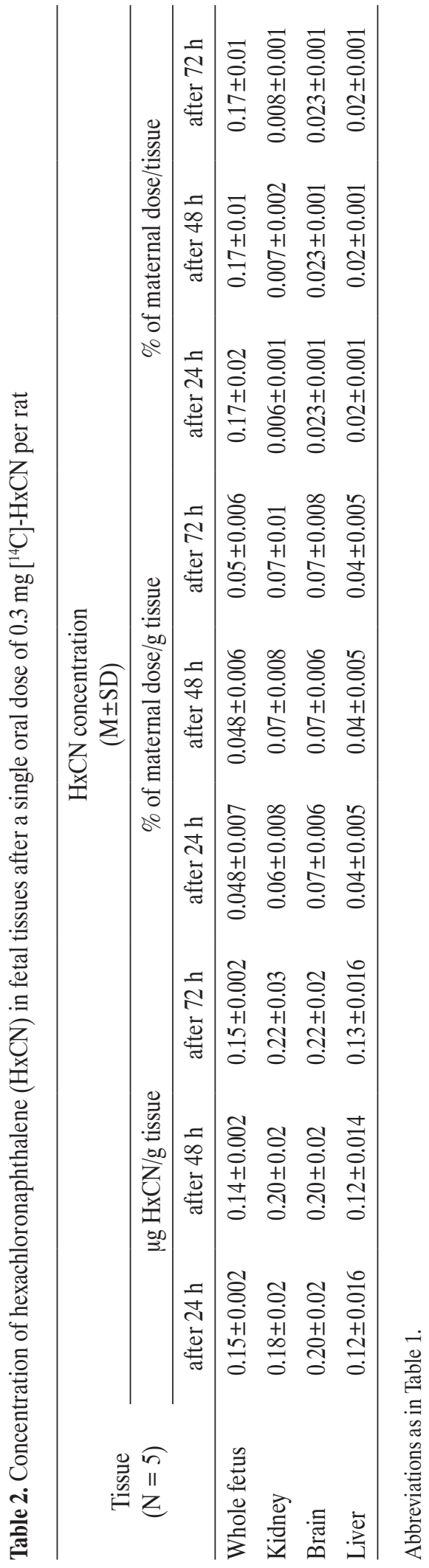

high repeatability. Noteworthy is the fact that the concentrations of $\mathrm{HxCN}$ in the fetal kidneys and brains (approx. $0.2 \mu \mathrm{g} / \mathrm{g}$ tissue for both organs) were almost 1.5 times higher than the concentration observed in the maternal blood $(0.16 \mu \mathrm{g} / \mathrm{g}$ tissue). In contrast, the lowest $\mathrm{HxCN}$ levels were observed in the fetal livers.

\section{DISCUSSION}

Although there is no conclusive data demonstrating that the POP compounds are dangerous for pregnant women, it has been reported that children whose mothers during pregnancy were consuming fish from the Great Lakes in North America, known to be contaminated with organochlorine compounds including PCNs [23,31], often manifested delays in psychomotor development and lower intelligence quotient (IQ) [32]. Moreover, a study on the population of women from northern Quebec who also consumed contaminated fish during pregnancy demonstrated a correlation between the significantly increasing activity of CYP1A1 in the placenta and low birth weight [33].

Few prenatal toxicity studies have been performed on the impact of polychlorinated naphthalenes on experimental animals $[20,21,34]$. A review of the literature shows that even a single exposure of pregnant rats to doses non-toxic to the mother may lead to adverse health effects in the offspring. For example, administration of hexachloronaphthalene $(\mathrm{HxCN})$ (a dose of $1 \mu \mathrm{g} / \mathrm{kg}$ ) to pregnant rats during organogenesis is associated with an accelerated start of spermatogenesis in male offspring [34]. In addition, exposure of pregnant females to a mixture of PCNs roughly corresponding to that used in the past (technical Halowax 1013 and 1014) was found to induce embryotoxic, fetotoxic and even teratogenic effects [21]. Embryotoxic and fetotoxic effects, combined with very strong CYP1A1 induction in the placenta and in the maternal and fetal livers, were also recorded after the administration of hexachloronaphthalene to the dams [20]. This strong induction of the CYP1A1 isoform is characteristic 
of dioxins and indicates the affinity of PCNs to the Ah receptor $[20,25,27,35]$. Studies on porcine ovarian follicles also showed that higher chlorinated naphthalene levels lead to toxic effects similar to that of dioxins influencing steroidogenesis as well as androgenic and anti-estrogenic properties [36,37].

To assess the transplacental transfer of various drugs, a rat or mouse model is often used. Despite the structural differences in the placenta of these rodents and humans there are many overlapping characteristics [38], such as the histological structure (the same haemochorial type) [39] and waveforms in rodents that are similar to humans for both uterine and umbilical arteries [38]. A range of mechanisms exist, by means of which various toxic substances may be transferred through the placenta from the mother to the fetus: passive diffusion, facilitated diffusion, transporter mediated transport, pinocytosis and filtration [40]. Despite the protective role of the placenta, many POPs (including PCNs) penetrate into the fetal body [19].

It seems that in the process of transplacental transfer of dioxin and dioxin-like compounds, physiochemical properties, especially lipid solubility, could play a critical role in the distribution of particular congeners in the fetus [41]. For example, studies of human cord blood serum found the dominant congener of dioxins to be octachlorodibenzo-p-dioxin (octaCDD) and that of polychlorinated naphthalenes $\mathrm{HxCN}$ [19], which are characterized by the highest values of the octanol-water partition coefficient $\left(\mathrm{K}_{\mathrm{OW}}\right)[42,43]$. The concentrations of PCNs were at comparable levels with those of PCDDs/PCDFs. Furthermore, the TEQs of PCNs equaled approx. 25\% of the total TEQs established in human cord blood samples [19]. These findings indicate that PCNs have great importance among other POPs as far as their accumulation in the fetal body and the consequent adverse health effects are concerned.

As this is the first study to investigate the placental transport of hexachloronaphthalene to rat fetuses, ob- tained results were compared with studies performed for substances with similar physicochemical properties and toxicity, such as 2,3,7,8-tetrachlorodibenzo- $p$-dioxin (TCDD). Our study found the maternal liver disposition of $\mathrm{HxCN}$ (GD20) to be in line with that characterizing TCDD (GD21); 25.2 and 25.5\% dose/whole compartment, respectively [44]. Chen et al. [44] and Hurst et al. [45] also report that maternal liver TCDD sequestration is dose-dependent and low concentrations penetrate better to the maternal liver than the fetal liver. This is probably related to the better absorption and penetration of lower concentrations through the placenta. The results obtained in our research for the placenta $(0.06 \%$ dose $/ \mathrm{g})$ are consistent with higher placenta concentrations $(0.043 \%$ dose $/ g)$ after the lowest doses of TCDD.

To examine the retention in the liver and adipose tissue from dams, the L/A ratio was determined. Our findings indicate that the $\mathrm{L} / \mathrm{A}$ ratio decreased with time after administration, which is comparable with the results observed by Chen et al. [44]. The gradually increasing concentration of $\mathrm{HxCN}$ in the adipose tissue after administration was also observed in a previous study on the distribution of this compound in male rats [24]. Our present findings also indicate that $\mathrm{HxCN}$ penetrates into the fetus, reaching a level of $0.05 \%$ dose $/ g$ tissue, which is comparable to the findings obtained by Chen et al. [44] following the exposure of the subjects to TCDD ( $0.053 \%$ dose/g tissue). The tested compound was also confirmed to penetrate easily through the placenta at similar $\mathrm{HxCN}$ values in the fetuses $(0.15 \mu \mathrm{g} / \mathrm{g}$ tissue $)$ and in the blood collected from the mothers $(0.16 \mu \mathrm{g} / \mathrm{g}$ tissue $)$.

In the case of mothers, the greatest retention was observed in the livers, while the opposite was observed in the fetuses; similarly, earlier studies on the distribution of hexachloronaphthalene in male rats also found the highest concentration to be in the liver [24]. This is probably due to the differences present in the fetal liver circulation. During fetal life, blood flows through the ductus venosus 
without crossing the liver. This unique mechanism protects the fetal liver from the need to transform the maternal toxic substances [46].

It is particularly noteworthy that, relatively high levels of the compounds were also found in the uterus and ovaries. In addition, studies on porcine ovarian follicles have also found PCNs to have a negative impact on the female sexual reproductive system regarding hormone secretion [37]. It has been proven that they may cause reproductive disorders in females.

Analyzing the results in various fetal organs, the highest levels of $\mathrm{HxCN}$ were found in the brains (average $0.2 \mu \mathrm{g} / \mathrm{g}$ tissue), these levels being similar to those observed in the brains of the mothers (average $0.24 \mu \mathrm{g} / \mathrm{g}$ tissue). Even higher levels of $\mathrm{HxCN}$ were observed in the sciatic nerve of the mothers $(0.3 \mu \mathrm{g} / \mathrm{g}$ tissue). This demonstrates the high affinity of the analyzed compound to the nervous system and potential induction of neurotoxic effects. Similarly, neurotoxicity was confirmed by previous studies showing neurobehavioral effects [47] and changes in gamma-aminobutyric acid (GABA)-metabolizing enzymes in rat brains [48].

\section{CONCLUSIONS}

In summary, the paper examines the concentrations of hexachloronaphthalene in the maternal tissues and in the transplacental transfer of the tested compound to the fetuses. Exposure of pregnant rats to $\mathrm{HxCN}$ results in the accumulation of the compound in the maternal liver, fat tissue, reproductive and nervous system, and especially in the brains of the fetuses. Our data confirms that $\mathrm{HxCN}$ tissue concentrations were comparable to those in the TCDD study. The penetration of TCDD into the fetus is dosedependent, with a greater percentage of the dose reaching the fetus at lower doses of TCDD. The results presented in this paper concern the exposure of pregnant females to a single dose of $\mathrm{HxCN}$, therefore extrapolation of these findings to varied doses may underpredict the exposure of the offspring. The diverse levels of exposure of pregnant females to $\mathrm{HxCN}$ and the degree of the infiltration to fetuses should be investigated in the future.

\section{ACKNOWLEDGMENTS}

The authors would like to thank dr Małgorzata SkrzypińskaGawrysiak for her helpful advice on various technical issues examined in this paper.

\section{REFERENCES}

1. World Health Organization. Concise International Chemical Assessment Document (CICAD). Vol. 34. Chlorinated naphthalenes. Geneva: The Organization; 2001.

2. Stockholm Convention [Internet]. Châtelaine: Stockholm Convention Clearing House; c2015 [cited 2017 Sep 18]. Available from: http://www.pops.int.

3. Falandysz J. Polychlorinated naphthalenes: An environmental update. Environ Pollut. 1998;101(1):77-90, https://doi. org/10.1016/S0269-7491(98)00023-2.

4. Liu G, Cai Z, Zheng M. Sources of unintentionally produced polychlorinated naphthalenes. Chemosphere 2014;94:1-12, https://doi.org/10.1016/j.chemosphere.2013.09.021.

5. Odabasi M, Dumanoglu Y, Kara M, Altiok H, Elbir T, Bayram A. Polychlorinated naphthalene ( $\mathrm{PCN})$ emissions from scrap processing steel plants with electric-arc furnaces. Sci Total Environ. 2017;574:1305-12, https://doi.org/10.1016/j. scitotenv.2016.08.028.

6. Orlikowska A, Hanari N, Wyrzykowska B, Bochentin I, Horii Y, Yamashita N, et al. Airborne chloronaphthalenes in Scots pine needles of Poland. Chemosphere. 2009;75(9): 1196-205, https://doi.org/10.1016/j.chemosphere.2009.02.024.

7. Xu Y, Li J, Chakraborty P, Syed JH, Malik RN, Wang Y, et al. Atmospheric polychlorinated naphthalenes (PCNs) in India and Pakistan. Sci Total Environ. 2014;1(466-467): 1030-6, https://doi.org/10.1016/j.scitotenv.2013.07.078.

8. Falandysz J. Chloronaphthalenes as food-chain contaminants: A review. Food Addit Contam. 2003;20(11):995-1014, https://doi.org/10.1080/02652030310001615195. 
9. Martí-Cid R, Bocio A, Llobet JM, Domingo JL. Intake of chemical contaminants through fish and seafood consumption by children of Catalonia, Spain: Health risks. Food Chem Toxicol. 2007;45(10):1968-74, https://doi.org/10.1016/ j.fct.2007.04.014.

10. Marti-Cid R, Lobet JM, Castel V, Domingo JL. Human exposure to polychlorinated naphthalenes and polychlorinated diphenyl esters from foods in Catalonia, Spain: Temporal trend. Environ Sci Technol. 2008;42(11):4195-201, https:// doi.org/10.1021/es800064p.

11. Li L, Sun S, Dong S, Jiang X, Liu G, Zheng M. Polychlorinated naphthalene concentrations and profiles in cheese and butter, and comparisons with polychlorinated dibenzo-p-dioxin, polychlorinated dibenzofuran and polychlorinated biphenyl concentrations. Int J Environ Anal Chem. 2015;9(3):203-16, https://doi.org/10.1080/03067319.2014.1002491.

12. Falandysz J, Fernandes A, Gregoraszczuk E, Rose M. The toxicological effects of halogenated naphthalenes: A review of aryl hydrocarbon receptor-mediated (dioxin-like) relative potency factors. J Environ Sci Health. Part C. 2014;32(3):239-72, https://doi.org/10.1080/10590501.2014. 938945.

13. Weistrand C, Noren K. Polychlorinated naphthalenes and other organochloride contaminants in human adipose tissue and liver. J Toxicol Environ Health A. 1998;53(4):293-311, https://doi.org/10.1080/009841098159295.

14. Kunisue T, Johnson-Restrepo B, Hilker DR, Aldous KM, Kannan K. Polychlorinated naphthalenes in human adipose tissue from New York, USA. Environ Pollut. 2009;157(3): 910-5, https://doi.org/10.1016/j.envpol.2008.11.012.

15. Schiavone A, Kannan K, Horii Y, Focardi S, Corsolini S. Polybrominated diphenyl ethers, polychlorinated naphthalenes and polycyclic musks in human fat from Italy: Comparison to polychlorinated biphenyls and organochloride pesticides. Environ Pollut. 2010;158(2):599-606, https://doi. org/10.1016/j.envpol.2009.08.011.

16. Lunden A, Noren K. Polychlorinated naphthalenes and other organochloride contaminants in Swedish human milk,
1972-1992. Arch Environ Contam Toxicol. 1998;34(4):41424, https://doi.org/10.1007/s002449900338.

17. Witt K, Niessen KH. Toxaphenes and chlorinated naphthalenes in adipose tissue of children. J Pediatr Gastroenterol Nutr. 2000;30(2):164-9, https://doi.org/10.1097/00005176-20 0002000-00013.

18. Environmental Working Group. Pollution in people. Cord blood contaminants in minority newborns [Internet]. Washington: The Group; 2009 [cited 2017 September 18]. Available at https://static.ewg.org/reports/2009/minority_cord_blood/ 2009-Minority-Cord-Blood-Report.pdf.

19. Kim JT, Son MH, Lee DH, Seong WJ, Han S, Chang YS. Partitioning behavior of heavy metals and persistent organic pollutants among feto-maternal bloods and tissues. Environ Sci Technol. 2015;49(12):7411-22, https://doi.org/10.1021/es 5051309 .

20. Kilanowicz A, Czekaj P, Sapota A, Skrzypińska-Gawrysiak M, Bruchajzer E, Daragó A, et al. Developmental toxicity of hexachloronaphthalene in Wistar rats. A role of CYP1A1 expression. Reprod Toxicol. 2015;58:93-103, https://doi. org/10.1016/j.reprotox.2015.09.005.

21. Kilanowicz A, Sitarek K, Skrzypińska-Gawrysiak M, Sapota A. Prenatal developmental toxicity of polychlorinated naphthalenes (PCNs) in the rat. Ecotoxicol Environ Saf. 2011; 74(3):504-12, https://doi.org/10.1016/j.ecoenv.2010.08.025.

22. Asplund L, Jakobsson E, Haglund P, Bergman A. 1,2,3,5,6,7-hexachloronaphthalene - Selective retention in rat liver and appearance in wildlife. Chemosphere. 1994;28(12):2075-86, https://doi.org/10.1016/0045-6535(94) 90177-5.

23. Hanari N, Kannan K, Horii Y, Taniyasu S, Yamashita N, Jude DJ, et al. Polychlorinated naphthalenes and polychlorinated biphenyls in benthic organisms of a Great Lakes food chain. Arch Environ Contam Toxicol. 2004;47(1): 84-93, https://doi.org/10.1007/s00244-003-3106-6.

24. Kilanowicz A, Daragó A, Skrzypińska-Gawrysiak M. The effect of exposure route on the distribution and excretion of hexachloronaphthalene in rats. Int J Occup Med Environ 
Health. 2012;25(2):185-95, https://doi.org/10.2478/S13382012-0021-y.

25. Blankenship AL, Kannan K, Villalobos SA, Villeneuve D, Falandysz J, Imagawa T, et al. Relative potencies of individual polychlorinated naphthalenes and Halowax mixtures to induce Ah receptor-mediated responses. Environ Sci Technol. 2000;34(15):3153-8, https://doi.org/10.1021/es9914339.

26. Villeneuve DL, Kannan K, Khim JS, Falandysz J, Nikiforov VA, Blankenship AL, et al. Relative potencies of individual polychlorinated naphthalenes to induce dioxin-like responses in fish and mammalian in vitro bioassays. Arch Environ Contam Toxicol. 2000;39(3):273-81, https://doi. org $/ 10.1007 / \mathrm{s} 002440010105$.

27. Kilanowicz A, Skrzypińska-Gawrysiak M. The toxicity of hexachloronaphthalene $(\mathrm{HxCN})$ and induction of CYP1A in rats. Ecotoxicol Environ Saf. 2010;73(2):196-205, https:// doi.org/10.1016/j.ecoenv.2009.08.018.

28. Directive 2010/63/EU of the European Parliament and of the Council of 22 September 2010 on the Protection of Animals Used for Scientific Purposes. Off J Eur Union L 276/33, p. 33-79 (Oct 20, 2010).

29. Mahin DT, Lofberg RT. A simplified method of samples preparation for determination of tritum, carbon 14 or sulfur 35 in blood or tissue by liquid scintillation counting. Anal Biochem. 1966;16(3):500-9, https://doi.org/10.1016/0003-26 97(66)90233-8.

30. Hurst CH, Abbott BD, DeVito MJ, Birnbaum LS. 2,3,7,8-Tetrachlorodibenzo-p-dioxin in pregnant Long Evans rats: Disposition to maternal and embryo/fetal tissues. Toxicol Sci. 1998;45(2):129-36, https://doi.org/10.1006/toxs. 1998.2520.

31. Kannan K, Yamashita N, Imagawa T, Decoen W, Khim JS, Day RM, et al. Polychlorinated naphthalenes and polychlorinated biphenyls in fishes from Michigan waters including the Great Lakes. Environ Sci Technol. 2000;34(4):566-72, https://doi.org/10.1021/es990966e.

32. Rodier PM. Environmental causes of central nervous system maldevelopment. Pediatrics 2004;113(Suppl. 4):1076-81.
33. Pereg D, Dewailly E, Poirier GG, Ayotte P. Environmental exposure to polychlorinated biphenyls and placental CYP1A1 activity in Inuit women from northern Québec. Environ Health Perspect. 2002;110(6):607-12.

34. Omura M, Masuda Y, Hirata M, Tanaka A, Makita Y, Ogata R, et al. Onset of spermatogenesis is accelerated by gestational administration of 1,2,3,4,6,7-hexachlorinated naphthalene in male rat offspring. Environ Health Perspect. 2000;108(6):539-44, https://doi.org/10.1289/ehp. 00108539 .

35. Hooth MJ, Nyska A, Fomby LM, Vasconcelos DY, Vallant M, DeVito MJ, et al. Repeated dose toxicity and relative potency of 1,2,3,4,6,7-hexachloronaphthalene (PCN66) 1,2,3,5,6,7-hexachloronaphthalene (PCN67) compared to 2,3,7,8-tetrachlorodibenzo-p-dioxin (TCDD) for induction of CYP1A1, CYP1A2 and thymic atrophy in female Harlan Sprague-Dawley rats. Toxicology. 2012;301(1-3):5-93, https://doi.org/10.1016/j.tox.2012.07.005.

36. Gregoraszczuk Et, Jerzak J, Rak-Mardyła A, Falandysz J. Halowax 1051 affects steroidogenesis, 17ß-hydroxysteroid dehydrogenase (17 $\beta$-HSD) and cytochrome P450arom (CYP19) activity, and protein expression in porcine ovarian follicles. Reprod Toxicol. 2011;32(4):379-84, https://doi. org/10.1016/j.reprotox.2011.09.008.

37. Barć J, Gregoraszczuk EL. Effects of individual polychlorinated naphthalene (PCN) components of Halowax 1051 and 2 defined, artificial PCN mixtures on AHR and CYP1A1 protein expression, steroid secretion and expression of enzymes involved in steroidogenesis (CYP17, 17-HSD and CYP19) in porcine ovarian follicles. Toxicology. 2014;322: 14-22, https://doi.org/10.1016/j.tox.2014.04.010.

38. Dilworth MR, Sibley CP. Review: Transport across the placenta of mice and women. Placenta. 2013;34 Suppl:S34-9, https://doi.org/10.1016/j.placenta.2012.10.011.

39. Furukawa S, Kuroda Y, Sugiyama A. A comparison of the histological structure of the placenta in experimental animals. J Toxicol Pathol. 2014;27(1):11-8, https://doi.org/10. 1293/tox.2013-0060. 
40. Myllynen P, Pasanen M, Pelkonen O. Human placenta: A human organ for developmental toxicology research and biomonitoring. Placenta. 2005;26(5):361-71, https://doi.org/10.10 16/j.placenta.2004.09.006.

41. Tsukimori K, Morokuma S, Hori T, Takahashi K, Hirata T, Otera Y, et al. Characterization of placental transfer of polychlorinated dibenzo- $p$-dioxins, dibenzofurans and polychlorinated biphenyls in normal pregnancy. J Obstet Gynaecol Res. 2013;39(1):83-90, https://doi.org/10.1111/j.14470756.2012.01906.x.

42. Shiu WY, Doucette W, Gobas FAPC, Andren A, Mackay D. Physical-chemical properties of chlorinated dibenzo- $p$-dioxins. Environ Sci Technol. 1988;22(6);651-8, https://doi.org/ 10.1021/es00171a006.

43. Puzyn T, Falandysz J. Application and comparison of different chemometric approaches in QSPR modelling of supercooled liquid vapour pressures for chloronaphthalenes. SAR QSAR Environ Res. 2007;18(3-4):299-313, https://doi. org/10.1080/10629360701303875.

44. Chen CY, Hamm JT, Hass JR, Birnbaum LS. Disposition of polychlorinated dibenzo-p-dioxins, dibenzofurans, and non-ortho polychlorinated biphenyls in pregnant long evans rats and the transfer to offspring. Toxicol Appl Pharmacol. 2001;173(2):65-88, http://doi.org/10.1006/taap.2001.9143.

45. Hurst CH, DeVito MJ, Setzer RW, Birnbaum LS. Acute administration of 2,3,7,8-tetrachlorodibenzo- $p$-dioxin (TCDD) in pregnant Long Evans rats: Association of measured tissue concentrations with developmental effects. Toxicol Sci. 2000;53(2):411-20, https://doi.org/10.1093/toxsci/53.2.411.

46. Horta ML, Lemonica IP. [Placental transfer and embryofetal effects of drugs used in anesthesia]. Rev Bras Anestesiol. 2002;52(1):101-13, https://doi.org/10.1590/S0034-7094 2002000100012. Portuguese.

47. Kilanowicz A, Wiaderna D, Lutz P, Szymczak W. Behavioral effects following repeated exposure to hexachloronaphthalene in rats. Neurotoxicology. 2012;33(3):361-9, https://doi. org/10.1016/j.neuro.2012.02.011.

48. Vinitskaya H, Lachowicz A, Kilanowicz A, Bartkowiak J, Żylińska L. Exposure to polychlorinated naphthalenes affects GABA-metabolizing enzymes in rat brain. Environ Toxicol Pharmacol. 2005;20(3):50-5, https://doi.org/10.10 16/j.etap.2005.05.004.

This work is available in Open Access model and licensed under a Creative Commons Attribution-NonCommercial 3.0 Poland License - http://creativecommons.org/ licenses/by-nc/3.0/pl/deed.en. 